\title{
Looking back on 20 years of NCK
}

\author{
J. Dronkers \\ Deltares, P.O. Box 177, 2600 MH, Delft, The Netherlands, Job.Dronkers@deltares.nl
}

I will be retiring this year. That is an additional reason for me to look back on 20 years of NCK. I see the NCK as one of the most significant initiatives in my discipline in which I was involved during my career. It brings me a sense of contentment that I could contribute to this initiative.

The NCK overlaps with a bloom in Dutch coastal research. That is due to the work of many. But in my experience, certain persons played a key role in that they provided innovative impulses to our coastal research. That I am highlighting them in my retrospective should not be interpreted as a denial of the significance of many others. Among these many others who I should perhaps have mentioned are colleagues in other countries who have enriched the discipline with insights that we have gratefully used in the Netherlands.

The NCK did not just happen overnight. We had the privilege of being able to build on a particularly bountiful inheritance. With that, I would like to start my retrospective.

\section{- PRELUDE - \\ A FEW IMPORTANT MILESTONES}

When the storm surge barrier in the Eastern Scheldt became operational in 1986, people felt that the Netherlands had completed its battle against the sea. The vision of Johan van Veen, the spiritual father of the Delta Plan, had been realized. Although that dam in the Eastern Scheldt could have been a closed one, as far as he was concerned.

Johan van Veen was a visionary and, moreover, a tenacious gogetter, in spite of how modest he might appear to outsiders. One of his starting points was: In order to beat the enemy, you first have to get to know him well. In the 1930s, for example, he had investigated tidal currents in the North Sea so as to understand how they were influenced by seabed morphology. His $\mathrm{PhD}$ thesis of 1936 gives evidence of deep insight in physical oceanography. We could call Johan van Veen the first Dutch morphologist, but the term did not exist yet at the time. At Rijkswaterstaat (the executive arm of the Dutch Ministry of Infrastructure and the Environment), he had established the Algemene Studiedienst, where young engineers and a young mathematician - my father were challenged to learn how to simulate hydrodynamic processes for major interventions in the coastline, after the example of the great physicist Hendrik Lorentz. Because already back then, long before the disastrous storm surge of 1953, Johan van Veen knew that the Netherlands needed a Delta Plan to remain safe from flooding.

But the battle against the sea had not been won yet after the construction of the Eastern Scheldt storm surge barrier. Calculations with the electrical simulator "Deltar" - also one of Van Veen's brainchildren - showed that the lower river region was not yet sufficiently protected. The Deltar, an ingenious machine which heavily taxed The Hague's electricity grid, soon was replaced by the first numerical mathematical models, however. They confirmed the precarious situation of the lower river region and offered the possibility of calculating various hydraulic engineering solutions. Eventually, this led to the design of the storm surge barrier in the New Waterway, which was finished in 1997.

Meanwhile, the way the Netherlands thought of its relationship with water had changed radically. The idea that we could win the fight against the water once and for all was replaced by the awareness that we had to deal differently with water. "Omgaan met Water" (Dealing with Water) was the title of a memorandum written by a team of young scientists, led by Henk Saeijs, in 1985 . Henk Saeijs, a former plantation manager in Sumatra in the 1950s, studied biology in Wageningen upon his return to the Netherlands. He was driven, a goldmine of ideas, and a charismatic inspirer. As head of the environmental department of Rijkswaterstaat in Middelburg, he was closely involved in the Eastern Scheldt studies. It gave him the insight that technological solutions alone cannot provide definite answers for water problems facing the Netherlands. The ideas of Saeijs can be seen as the first pointers toward the concept of "Building with Nature", which the NCK later shaped. But Omgaan met Water went further, as it did not only incorporate natural processes, but also offered a home to societal processes in solving water problems. Omgaan met Water was the overture to Integral Water Management and also a source of inspiration for Integrated Coastal Management.

At that same environmental department, which was initially located in 's Heer-Arendskerke, the first steps on the road to morphodynamics were taken at the start of the 1970s. Joost Terwindt had been appointed to study the effects of the constructions in the Eastern Scheldt on the development of the salt marshes and shoals. An important question that had to be answered first was: In which conditions do salt marshes and shoals develop? The research was carried out by a team of young physical geographers, led by Luc Kohsiek. Luc Kohsiek, currently dike warden in the Province of Noord-Holland and previously substitute Director-General at Rijkswaterstaat, is a tawny and confident guy, with a special talent for pinpointing the essence of complex matters and translating them into appealing images. The result of the investigation was a bit of a jolt for the builders of storm surge barrier. The new concept of "zandhonger" - sand demand - entered the stage: The salt marshes and shoals were doomed to disappear over time as a result of the construction of the barrier and the compartmentalization dams. This tough lesson also contributed toward readying people's mind for the notion of "Building with Nature".

Some others had started even earlier to venture into the area of morphodynamics. While working on his $\mathrm{PhD}$ in the 1950s, Henk Postma, geochemist at the NIOZ (Royal Netherlands Institute for Sea Research) on Texel, became puzzled by the phenomenon of 
shoal accretion in the Wadden Sea. He came up with the ingenious mechanism of settling lag, the lagging of resuspension after sedimentation, which explains how net transport is possible in an oscillating flow. It was not until decades later that it became clear how important the non-linearity of transport processes is for the morphodynamics of tidal basins. Later, Henk Postma would inspire many young scientists to unravel more details of the processes of self-organization in tidal systems, when he was director of NIOZ. The work done in this area by Sjef Zimmerman and his own students after him, including Huib de Swart, is globally seen as ground-breaking. Not surprisingly, the field of morphodynamics became one of the main pillars of the NCK's research.

After the flood disaster of 1953, the focus had shifted away from the dune coast. After all, the dune coast had shouldered the storm. Still, the dune coast was not doing very well in many locations. One engineer at Rijkswaterstaat had already put his teeth into the issue, T. Edelman. In those days, engineers hardly ever wrote scientific publications and Edelman adhered to that tradition. His work therefore is not very well known, but no less important. Edelman noticed how strongly coastal profiles fluctuate from year to year, as well as seasonally. Periods of strong erosion, during storms, alternate with periods of coastal accretion, in calm conditions, while long-term trends hide behind these fluctuations. He did not only see these processes through the glasses of the engineer, but also through the glasses of the geologist who looks for connections at greater spatial and temporal scales. He realized that long systematic series of measurements were paramount, in this respect. It is notably due to him that that Rijkswaterstaat started its annual coastal measurements in 1964. All Dutch coastal morphologists as well as the NCK owe Edelman for having been the instigator of the JARKUS program and for his far-reaching views.

Edelman's work did not escape the attention of everyone. In 1984, the "Directie Noordzee" was established, which among other things was responsible for the management of what we call the coastal foundation ("kustfundament") nowadays. Chief engineer Cees van den Burgt had hired a physical geographer to that end. Hans Wiersma notably had a broad view and was a networker pur sang. Someone with whom you enjoy having a drink and who will not let you pin him to a formal job description. He realized that an interplay of disciplines was required to tackle the erosion problems of the coast, by making connections between coastal processes at various time scales - from surf beat to coastal genesis. He managed to get a special group of people to sit down at the table, including the geologists and geographers Saskia Jelgersma, Dirk Beets and Joost Terwindt, and the hydraulic engineers Cees d'Angremond, Herman Wind, Huib de Vriend, Marcel Stive and Jan van de Graaff. He also came up with the name of the project aimed at advancing our understanding of coast-forming processes: Kustgenese (Coastal Genesis).

Next, Rijkswaterstaat had to be convinced. Walter Van der Kleij ruled over the A division (in which A is the acronym for Aqua), which is currently part of the I\&M Directorate-General Water en Ruimte; although he was of small stature, people looked up to him. When the ideas about Kustgenese had ripened sufficiently, Van den Burgt hopped on his bicycle to update Van der Kleij. He was successful: Finances were secured and Van der Kleij became a sort of godfather to Kustgenese. In those days, people started speculating about increased sea level rise as a result of global warming. Kustgenese was given the assignment to look into that as well. Ton Kuik became project manager of Kustgenese, which meanwhile had grown into a mega project in which dozens of researchers were involved. There was a need for clear targets and tight coordination, a role for which information analyst Ton Kuik was particularly well suited.

The insights from Kustgenese were ground-breaking and gave rise to a fundamental revision of Dutch coastal policy. The first person to see that was Tjalle de Haan, at the time Van der Kleij's policy officer. The traditional ideas about coastal defense were abandoned: Hard constructions like seawalls were abolished in favor of sand nourishment and natural dynamics. This newfangledness, later summarized in the motto "soft where possible, hard where required", initially met with incomprehension and resistance from managers and politicians. People spoke about "carrying sand to the sea", with horror. Tjalle de Haan has Frisian blood and is stubborn; he won't let go, once he is certain of something. In 1990, the memorandum "Kustverdediging na 1990" was sent to the House of Representatives, in order to determine the new Dutch coastal policy. From now on, funds for sand nourishment along the coast would be set aside in the government's budget, with sand mined offshore in the North Sea, such that there would be no deterioration of the Dutch coast, at any location.

\section{ESTABLISHMENT OF THE NCK}

When the last one of the 23 supporting studies of Kustgenese was submitted and Dutch Parliament had agreed on the coastal memorandum, a post-partum depression was hanging over the research community of Kustgenese. Hans Wiersma sensed that perfectly well, and launched the idea of a permanent association: An organization that was to retain the multidisciplinary cooperative spirit of Kustgenese by ensuring that the coastal researchers would be able to exchange ideas about their research projects. That is how the NCK came about.

The NCK started in 1992 with 4 partners, namely the parties that had contributed big time to Kustgenese: Delft University of Technology (departments of Fluid Mechanics and Hydraulic Engineering), WL | Delft Hydraulics, Utrecht University (IMAU) and Rijkswaterstaat (RIKZ). The directors of those partners had a seat on the Supervisory Board; their roles were predominantly ceremonial. The actual cooperation was to be shaped within the program commission, supported by the NCK secretariat. The first chair of the program commission was Joost Terwindt; Ad van Os was its secretary, and would remain so for 13 years. Joost Terwindt was succeeded in 1997 by yours truly, who in 2003 passed the baton to Piet Hoekstra. As of last year, 2011, Ad van de Spek is chair. The secretariat was taken over by Stefan Aarninkhof in 2004, by Mark van Koningsveld in 2006 and by Bert van der Valk in 2007. Claire van Oeveren became program secretary last year.

New partners have joined the NCK over the years: NITG-TNO (Geological Survey), the University of Twente (Civil Engineering and Management), NIOZ, NIOO-CEMO, UNESCO-IHE and Imares. These partners enriched the NCK with a host of new disciplines. However, physical coastal research has always remained at the core of the NCK. 


\section{WHAT IS THE NCK?}

The objectives drawn up at the launch of the NCK revealed a great deal of ambition:

- Quality improvement of coastal research through increased cooperation among research disciplines;

- Continuity of coastal research in the Netherlands through exchange of knowledge and methods among the partners;

- Maintaining fundamental coastal research at a sufficiently high level;

- Increasing knowledge exchange with the applied research community;

- Strengthening of coastal research and education at the Dutch universities;

- Enhancing the position of Dutch coastal research internationally.

As a result, the university partners obtained more research staff: 2.5 fte were financed by Rijkswaterstaat and 1.5 fte worth of senior researchers were made available by WL | Delft Hydraulics. The appointed researchers were given the task to design a research program for the NCK, submit it to the program commission for approval and subsequently take care of its execution by coordinating the research programs of the participating institutes.

In the eyes of the founders, the NCK was a continuation of the Kustgenese project. They probably did not realize fully yet that a new situation had developed after Kustgenese. Kustgenese was driven by an urgent societal question: How do we fight the continuous retreat of the Dutch coast? After Kustgenese, this question had received sand nourishment strategies as a reply. In addition, Kustgenese had generous earmarked funding and a relatively pristine research field in front of it, where pearls were easy to find.

The NCK lacked these ingredients. As a result, the program commission did not have a clear focus. The university groups, of course, each selected the discipline in which they could shine scientifically. The non-university partners carried out demanddriven research, which did not easily fit within the long-term research topics of the NCK program. The program commission did not actually have that much coordination to do. In spite of that, the somewhat misleading designation program commission has always remained.

The immediate impact of research in policy and management of the coast had been an important catalyst for entangling various disciplines in coastal research. That is why within the NCK, Rijkswaterstaat was assigned the important role as driver of knowledge integration. In addition, Rijkswaterstaat also had the roles of user of research results and research sponsor. Within the $\mathrm{NCK}$, there has always been a great deal of discussion about these roles of Rijkswaterstaat, certainly in the days when Rijkswaterstaat had its own coastal research department at the former RIKZ. Did the NCK assist Rijkswaterstaat or did Rijkswaterstaat assist the NCK? Should the NCK focus on societal benefits or predominantly on the advancement of knowledge? Opinions within the NCK differed. In 2007, the partners Rijkswaterstaat (RIKZ), TNO (RGD) and WL | Delft Hydraulics merged into the new institute Deltares, and the discussion about the immediate benefits of the NCK for coastal management and coastal policy ebbed away.
Cooperation does not go without saying. That is what I experienced when I was at the center of the NCK, as member and later as chair of the program commission. Researchers are headstrong people, who don't want to be told what to do. The differences of opinion in the program commission sometimes led to heated discussions. That we found a solution in spite of that was notably due to two persons who radiated so much wisdom that the rational mind eventually conquered emotion: Joost Terwindt and Marcel Stive. You can easily call them the "patres familias" of the NCK.

The NCK never was a programming or coordinating organization in coastal research. The NCK is in fact a network organization. As a network, the NCK functioned well for 20 years, and it ensured that researchers of the participating parties interacted with one another to exchange knowledge and cooperate. The greatest added value of the NCK is in the area of knowledge transfer between different research disciplines and knowledge transfer from experienced researchers to researchers who are just starting out.

Each year, the NCK days bring together a large number of people from the research community, while in addition, workshops on specific topics are organized frequently. The NCK summer school has already been a great success for ten years, enjoying increased interest every year, also from other countries. Its initiator was Huib de Swart who saw his summer school, originally focused on morphodynamics, grow into a multidisciplinary coastal research summer school. This success, in his eyes slightly too exuberant, meanwhile has caused him to organize a summer school on morphodynamics in parallel.

The NCK has ensured that every coastal researcher in the Netherlands can lean on the entire research community, and is able to use all models and instruments that have already been developed. These are conditions for gaining optimal yield from coastal research. To which special achievements did it lead? I will address that hereafter.

\section{REMARKABLE ACHIEVEMENTS, CATALYZED BY THE NCK}

\section{Coastal morphodynamics}

The term coastal morphodynamics is still new. I do not know who introduced the term, but it is quite clear who put the concept on the map. That is Huib de Vriend, who was the initiator and driving force for three large European projects (G6M, G8M and PACE) in the area of coastal morphodynamics, in the first years of the NCK. The phenomenon of morphodynamics had been known for some time, but the crucial importance of feedback mechanisms for the resilience of the coastal system was less well known, such as the tendency for autonomous recovery after extreme erosion or after human interventions. Better insight in these feedback mechanisms reveals possibilities for strengthening these selfregulating dynamics of the coast through smart interventions. The impulses by Huib de Vriend grew into a flourishing research branch within the NCK community; it attempts to fathom various aspects of morphodynamics and capture them in models.

The research of the inherent instability of coastal systems, which drives the formation of many coastal forms, was stimulated strongly by Huib de Swart. Huib de Swart developed 
mathematical methods for the analysis of instability development and he initiated a large number of $\mathrm{PhD}$ projects in this area. Is it due to the NCK that both Huibs, in spite of their rather self-willed characters, were able to inspire and complement each other? One of the PhD students of Huib de Swart, Suzanne Hulscher, subsequently established her own, internationally acclaimed research group for the study of the morphodynamics of the sea floor as full professor at the University of Twente.

The morphodynamics virus also infected the other NCK partners. A great deal of research into bank behavior off the Dutch coast under the influence of bound long waves was carried out at Delft University of Technology and at WL | Delft Hydraulics, inspired by Jurjen Battjes and Marcel Stive. Important contributions included those of Ad Reniers, Dano Roelvink and Gerben Ruessink. And many others, standing on the shoulders of these innovators, have contributed to the world-wide reputation of the Netherlands in the area of coastal morphodynamics research. I will later get back to the societal benefits of this kind of research.

\section{Mud}

The Netherlands has a sandy coast, yet mud plays an important role in it. The silting up of shipping channels and ports entails considerable maintenance costs. But there are many other aspects. The laboratory experiments of Jan van de Graaff and Paul Sistermans have shown, for example, that the physical properties of sandy soils can change significantly even if they contain only a small percentage of mud. This is also evident from the EemsDollard project on the erodibility of mudflat shoals, which was initiated by Joost Terwindt. But the presence of a small fraction of mud also has a large influence on the soil fauna and soil vegetation, which in turn determine physical soil properties such as erodibility, net sedimentation and roughness. Mudflats and tidal marshes therefore create their own conditions for their development and thus play an important role in the morphodynamics of tidal systems. The consequences of this new insight were investigated by Peter Herman and his research group at NIOO-CEMO. This knowledge appeared to be highly relevant for environmental impact studies and for projects of recovery and creation of nature areas.

From the early years of the NCK, studies were carried out to describe the physical properties of mud in models. The main pioneer in this area was Wim van Leussen, who recorded the flocculation behavior and the related sedimentation velocity of mud, with the mud camera he designed. Later, Johan de Kok and Han Winterwerp and others applied these insights and relationships in mathematical models, with which various mudrelated practical problems were analyzed, such as the occurrence of mud layers and turbidity maxima in estuaries and the mud recirculation from the Loswal to the Rotterdam Waterway. These models are also of great importance for understanding the primary production in the Dutch coastal waters. This ecosystem research largely takes place outside the NCK framework, however.

\section{Field research}

Nature does not always like its measurements taken. In 20 years of NCK, quite a few expensive measuring instruments were lost in the surf. Some more were dragged off by fishing gear. But that didn't discourage the NCK partners. After all, field data are essential for testing hypotheses regarding coastal behavior and for developing new theories. Initially, all field work was the exclusive domain of Rijkswaterstaat and of the physical geographers at Utrecht University. Jointly, they developed the tripod measurement frames, the WESP and the CRIS, which played an important role in corroborating Kustgenese's ideas on the effectiveness of the nourishment strategy for coastal preservation. This research was carried out in the European NOURTEC project initiated by Jan Mulder, in Rijkswaterstaat's KUST2000 program and in the EU project COAST3D coordinated by Leo van Rijn. In these projects, Aart Kroon, Gerben Ruessink and Piet Hoekstra organized the field work.

The Argus camera, a smart way of measuring in the surf zone, was imported from the US. As addition to the JARKUS measurements, this yielded insight into the short-term coastal behavior and, moreover, enabled monitoring of foreshore nourishments. Also owing to the advanced analysis software developed by Stefan Aarninkhof and other NCK members, the Argus camera is now a commonly used measuring instrument on beaches all over the world.

Another "exotic tool" is the jet ski which since a few years is used very successfully for coastal bathymetry surveys. Students from Delft ended the hegemony for field measurements in the Netherlands from Utrecht; their jet ski company is now also asked to carry out surveys in other countries. Other innovating measurement techniques are the MEDUSA measurement probe developed by Rob de Meijer at the University of Groningen, for quick scans of the sea floor surface composition, and the measurement kit which Herman Ridderinkhof of NIOZ has mounted on the ferry to Texel in order to gain better insight into the sediment exchange between the Wadden Sea and the coastal zone.

Considerable progress was made in techniques for the analysis and interpretation of coastal field data. Gerben de Boer of Deltares, for example, developed the OpenEarth system, which enables combining and visualizing coastal data, such that it yields much more information at a glance.

Observations sometimes have an immediate impact on coastal management. The first observations with the wave measurement set-up at Petten, for example, revealed that the period of storm waves off the Dutch coast had always been largely underestimated until then. That made clear that the safety level against flooding did not meet the requirements along the entire coast, as a result of which additional coastal reinforcement measures had to be taken.

\section{Models}

Every hypothesis can be considered a model. But in order to test theories for natural coastal configurations, to analyze observations or to carry out effect predictions, complex models are often required, in which processes are represented in great detail. In the 20 years of the NCK, an extensive model kit was developed, largely based on Guus Stelling's numerical solution methods. This model kit has been used as research means in many NCK projects and has contributed greatly to the advancement of knowledge.

An important component is the numerical wave model SWAN by Nico Booij and Leo Holthuisen, which has become the global standard for wave simulations in coastal waters. For the simulation of coastal morphology processes, Delft3DMOR is generally considered a top model around the world; major trumps of Delft3DMOR are the morphological time scaling procedure of Dano Roelvink and the sediment transport formulations of Leo 
van Rijn. These numerical models have paved the way for realistic simulations of non-linear processes in complex morphological systems, for instance, sediment exchange between tidal basins and the adjoining coastal zones and the development of the channeland-shoal systems in estuaries. The reliability of the model formulations was tested in a large number of real-life studies, including the EU projects SEDMOC and SANDPIT, coordinated by Leo Van Rijn. Especially for wave-dominated sandy coasts, Ap van Dongeren and Dano Roelvink developed the XBEACH model. Leo Postma and Han Winterwerp developed DELWAQ routines for the simulation of mud transport; among other things, they enabled an understanding of the very high turbidity of many European estuaries and investigated the effectiveness of repair measures. The model kit developed by NCK partners (predominantly WL | Delft Hydraulics and Delft University of Technology) over the years is frequently used by Dutch consultancies for complex coastal engineering projects around the world and contributes to the strong image of the Netherlands as the country of hydraulic engineering expertise.

Examples of the immediate importance of models for coastal management in practice are the drawing up of the sand budget for the Dutch coast and the quantification of nourishment requirements. Also, models have contributed to a new insight with far-reaching policy consequences. This was the case for the transport atlas of the North Sea by Will de Ruijter and Leo Postma, which showed that polluting substances that enter the Netherlands with the Rhine water at Lobith partly end up in the German Wadden Sea. This insight contributed to the large-scale remediation program of pollution sources along the entire Rhine river.

\section{Building with Nature}

The concept of "Building with Nature" was put on the map by Ronald Waterman. Building with Nature stands for a hydraulic engineering philosophy which breaks with the traditional practice of controlling the forces of the sea by means of hard constructions. Ir. T. Edelman and probably also several geologists already realized in the $1950 \mathrm{~s}$ that the forces of the sea not just aim at breaking down sand coasts, but more often produce coastal accretion. But it took several decades before this awareness was translated into the practice of hydraulic engineering. The Eastern Scheldt studies and Kustgenese provided the push for it. The practice of Building with Nature is founded on insight in the natural coastal processes and their self-organizing capacity. Without the knowledge of coastal morphodynamics accumulated in 20 years of NCK, the concept Building with Nature would have remained an empty shell.

Building with Nature is the hydraulic engineering practice which uses natural processes and materials naturally present in the coastal system, as much as possible. The best known application of Building with Nature is the foreshore nourishment strategy for coastal maintenance, which was studied extensively and optimized by the NCK partners. It became clear that natural processes (waves) do not only carry nourished sand from the breaker zone to the beach, but also contribute (wind) to strengthening of the dune zone and to increasing the dunes' drinking water storage capacity.

The Building with Nature concept for sandy shores was elaborated by Jan Mulder in the sand strategy. This sand strategy takes natural coastal morphology processes at different scales of time and space (for example, processes ranging from the time scale of a storm surge to the time scale of a meter of sea level rise) into consideration, in order to achieve sustainable coastal management. The Sand Engine at Kijkduin is a practical embodiment of this sand strategy.

Building with Nature is not only applicable to the maintenance of sandy coasts. Stimulating the development of vegetation offers possibilities for improving the safety of hard dams and dikes, while ecological values are restored or added. Edelman already wrote about this in the 1960s, and Tjalle de Haan had already started a subdivision on ecotechnology in Middelburg in the 1980s, in support of the Eastern Scheldt works. Mindert de Vries and colleagues of the biological and morphological disciplines at the NCK are presently developing and testing a wide range of new techniques. They call it eco-engineering: Ecosystem development aimed at optimizing societal services. Examples are the development of mussel beds (in the Wadden Sea) and oyster reefs (in the Eastern Scheldt) which absorb wave action, stimulate sedimentation, improve water quality as a result of their filtering action, and create a living environment for many other natural organisms that play a role in the marine food web. In short, assigning roles of hydraulic engineer and water manager to organisms!

\section{The Netherlands, \\ the world's top coastal engineering country}

Over the centuries, The Netherlands has built up a great reputation as a country with hydraulic engineering know-how. This reputation creates a lot of goodwill for the Netherlands and carries over to the economic position of the Netherlands in the world. It is therefore important for the Netherlands to maintain and enhance this reputation. The water sector, and notably coastal hydraulic engineering, is recognized as one of the top sectors of Dutch expertise for knowledge export. The NCK plays an important role in this: Through the hydraulic engineering innovations for which the NCK is a major breeding ground, and through the transfer of knowledge and experience within the NCK to new generations of water experts. Also owing to the NCK, knowledge of Building with Nature is currently an important new motor for the export of Dutch hydraulic engineering know-how to the rest of the world.

\section{CONCLUSION}

Quite some time ago, Johan van Veen, master of the sea, gave the example of how studying the fundamental properties of nature provides the insight in how to make the Netherlands safe and liveable. The NCK followed in these footsteps and has paved new roads in the past 20 years. But the sea keeps challenging us, both in the Netherlands and elsewhere on the planet. Work to do for a new generation of NCK people! 